\title{
Models of Higher Education Governance: A Comparison of Israel and Other Countries
}

\author{
Nitza Davidovitch \\ Ariel University of Samaria, Ariel 40700, Israel \\ E-mail: d.nitza@ariel.ac.il \\ Yaakov Iram \\ Ariel University of Samaria, Ariel 40700, Israel
}

Received: March 29, 2015

Accepted: April 25, 2015

Published: April 30, 2015

doi:10.5296/gjes.v1i1.7556

URL: http://dx.doi.org/10.5296/gjes.v1i1.7556

\begin{abstract}
Higher education governance refers to the legal appropriation of decision making power within universities between the various governance structures (faculty, academic committees, senates, and boards) and administrative structures (departments, programs, presidents, and vice presidents). The purpose of higher education governance is to articulate common public interests and to realize their goals while determining the limits of authority in theory and in practice - who shall decide and what is at the focus of decisions. From the late $19^{\text {th }}$ century until the early 1950s, university governance followed the principle of administrative autonomy, meaning that they were free to act and conduct themselves according to their own standards without bowing to the needs or demands of a funding government. However, the transition to a capitalist economy and society, in addition to the rapid rise in the number of students and the transformation of higher education into a mass commodity, required countries worldwide to seek new models of governance, with the aim of increasing academic order and efficiency. The different styles of governance can be charted along three main models, based on the mutual relations between market forces, the state, and higher education. The current paper reviews the various models of higher education governance and portrays the Israeli model. Finally, the strengths and weaknesses of each model are discussed, as well as the future of Israeli governance in light of local winds of change and global trends.
\end{abstract}

Keywords: Higher education, Autonomy, Governance models, Market forces 


\section{Introduction}

Higher education has undergone intensive change in recent decades, both in Israel and worldwide. While in the past it was the exclusive lot of the elite, from the mid-twentieth century higher education became accessible to the masses. This process of massification (Trow, 1973) was manifested in a sharp rise in the number of students in most Western countries (Lindberg, 2007; Toutkoushian \& Shafiq, 2010; Finnie \& Usher, 2007) affecting, among other things, the number, size, variety, and structure (Vaira, 2004) of schools of higher education worldwide. These changes, enhanced by the emergence of the "knowledge society" (Bridges, Juceviciene, Jucevicius, Mclaughlin, \& Stankeviciute, 2014), demographic developments, slow economic growth, globalization (Enders, 2004), and the growth of global competition (Dobbins \& Knill, 2014; Dobbins, Knill, \& Vögtle, 2011; Solanke, 2011), changed the face of higher education and necessitated a new approach to the regulation, control, and monitoring of this intricate developing system.

Most Western countries endeavored to deal with the changes noted above by implementing a large number of structural reforms aimed at changing the regulation patterns of higher education (De Boer \& File, 2009; Norton, 2014; McLendon, 2003). For example, the US; from 1985-2000, US states debated over 100 different proposals for reform (Note 1) in the authority and governance patterns, as well as the structure and function, of their higher education systems (McLendon, 2003). In European countries, dozens of reforms were attempted from the early 1980s, with the aim of restructuring the relationship between the state, society, and institutions of higher education (Dobbins \& Knill, 2009; Eurydice as cited in De Boer, Huisman \& Meister-Scheytt, 2010). In Australia a committee was convened with the purpose of examining the structure of governance and the changing needs for management of higher education institutions in the new global economy (Bradley, Noonan, Nugent, \& Scales, 2008). The committee published its conclusions in a final report (Bradley Report) which determined, among other things, that it is necessary to expand government regulation of higher education (Bradley et al., 2008). All the various structural reforms proposed and implemented throughout the world have one thing in common - they aim to find an optimal method of higher education governance on the institutional and systemic levels (De Boer \& File, 2009).

"Governance" in its general form refers to how the public together with the private sector solve social problems and generate social opportunities, as well as to how they deal with and care for those under their patronage. The purpose of governance is to articulate the common public interest and to realize its goals while determining the limits of authority in theory and in practice - who shall decide and what is at the focus of decisions. Governance in the field of higher education refers to the legal appropriation of decision making power within universities between the various governance structures (faculty, academic committees, senates, and boards) and administrative structures (departments, programs, presidents, and vice presidents). Furthermore, governance refers to the division of responsibility and accountability with regard to the authority to reach decisions (Corcoran, 2004). It is customary to distinguish between internal and external governance. Internal governance 


\section{MlMacrothink}

Global Journal of Educational Studies ISSN 2377-3936 2015, Vol. 1, No. 1

refers to management on the micro level; this is intra-institutional management that deals with determining procedures within institutions (for example: decision making processes, funding, filling positions, the limits of authority). External governance refers to systemic management and deals with institutional arrangements on the macro level (for example: rules and regulations, sources of funding, quality assessments). These two aspects, when combined and coordinated, form the structure of higher education governance (Boer \& File, 2009). Under this super-structure are rules, regulations, and policy arrangements that define the rights and obligations of the various actors and the nature of their mutual relationships.

The issue of higher education governance has been discussed in the research literature mainly with regard to its internal aspects (Pennock, Kezar, \& Eckel, 2004; Rowlands, 2013; Jones, Leclerc, \& Li, 2015), with the aim of empirically evaluating how to best manage the internal affairs of academic institutions. However, internal governance is inseparably connected to the nature and structure of external governance, which dictates the relationship mix between the state, market forces, and academic institutions (Neave, 2003), and thus in fact determines the degree of autonomy to structure internal governance. Israel, specifically, has a special interest in the issue of external governance (Note 2), particularly in light of the vagueness and the absence of designated legislation defining the agencies responsible for external regularization (the Council for Higher Education together with the Planning and Budgeting Committee). In the current paper we seek to review different models of external higher education governance and to examine them versus the Israeli model, and also to reach conclusions and recommendations concerning the Israeli model of governance.

\section{Literature Review: History of Higher Education Governance}

The first universities were religious schools that began flourishing in Europe in the late middle ages, from 1150-1500. Many social changes occurred in this period: the rise of mercantilism, accelerated urbanization, expansion of the middle class, bureaucratization, and the flourishing of the Renaissance - all these created the complexities of European society and formed the need to train professionals. The universities acted on this need and served as professional teaching institutions. They constituted guilds (Note 3) of teachers and students and were conducted as a type of corporation striving to maintain the group's interests. Their activities were rooted in the "soil of efficiency of the medieval period" (Cobban, 1992, p. 231), which perceived higher education as a functional issue that gives graduates a professional advantage manifested in financial terms. In this respect, the "medieval university was a school with a modern spirit" (Haskins, 1957, p. 25). The institutions operated as a partnership between teachers and students, and the government did not interfere with their activities and gave them complete management autonomy (Shechter, 2006). Although research was conducted at the universities, it was the result of individuals' initiatives rather than part of an institutional policy. The universities, which saw themselves as corporations, did not grant research degrees or appointments to research positions. The title Doctor - from the Latin docere (to teach) - was the highest degree granted and it certified its bearer to teach on the highest level. Despite the indirect contribution of the universities to creating an intellectual elite and graduates who became pillars of society, the universities saw themselves first and foremost as a professional organization acting to promote the well-being of its 
members (ibid.).

During the early modern era (1500-1800), with the rise of independent nation states - i.e., sovereign states with defined borders populated by citizens who share a sense of nationalism - the conception of the university underwent a transformation. The rise of the nation state interfered with academic autonomy, as academia became an institution in the service of the government/monarchy that assumed a role in structuring the state's institutions. As part of this function, the academic world engaged in teaching, research, and providing services to the community (Scott, 2006). The universities, controlled on the municipal level by the state, became a tool for expanding the government elite. The university was perceived as having a sociopolitical role and as an ideological branch of the government, with which it had a reciprocal relationship: "The state protects the action of the University; the University safeguards the thought of the state" (Readings, 1996, p. 69).

In 1810, with the establishment of the Berlin University by Wilhelm von Humboldt, this role of the university began to disappear. Humboldt proposed a model of academia that follows the principles of the unity of teaching and research (Note 4) and the principle of academic freedom to autonomously pursue knowledge and research (in German: lernfreiheit) - each according to his heart's desire (Commager, 1963). The autonomous function of higher education was at the heart of the Humboldtian approach, which exemplified higher education for many countries. This model had the greatest effect on shaping research universities worldwide, including the Israeli concept of higher education (Guri-Rosenblit, 2005; Zimmerman, 2005).

In time, universities all over the world transitioned to this dual academic model - research and teaching as the core of academic activity - while also embracing the principle of autonomy in the governance of higher education institutions. This principle created a sectorial concept of the higher education sector - i.e., a free-standing sector, not directly comparable with other types of organizations, including public organizations. This conception is a product of the ideology that perceives academia as a domain governed by academic autonomy, which also requires institutional autonomy in order to reach fruition (Ferlie, Musselin \& Andresani, 2008). This is the combination between the freedom to pursue research and to manage the institution without bowing to the needs or demands of a funding government. This structural-academic ideology led to a lengthy tradition in which the state was expected to limit its intervention in higher education. In this way, schools of higher education were transformed into public institutions that were both financed by public funds and protected from this same public and thus free to act according to their own standards.

This was the hegemonic approach in the public sphere until after World War II (on the changing relationship between the state and higher education see Salter \& Tapper, 2013). This period marked a point of transition in the governmental attitude to regulation and autonomy required for higher education governance (Graham, 1989; McLendon, 2003). The universities, which were autonomous institutions in the social milieu - self-managed public organizations that followed norms and standards they themselves had defined (Gal-Nur, 2009) - had to change according to the spirit of the times. Until that time the attitude to governance at public 
universities was very similar to that of private universities: boards of trustees on the campus level were responsible for the policy of the specific campus, independent of a larger official regulatory system. According to this approach, schools of higher education competed with each other for resources, students, and political patronage - in a market that was almost devoid of regulation (McLendon, Deaton, \& Hearn, 2007).

The transition to a capitalist economy and then to a capitalist society had a great impact on the status and conception of the universities, which were deeply criticized for their unsupervised conduct (Amaral, 2009). Organizations that had been oblivious to surrounding events began to attract attention, and were required to demonstrate accountability. Extensive discussion was initiated on the need for government involvement and intervention in higher education. The "ivory tower", once free to act guided by self-standards, was now required to subject itself to evaluation, regulation, and monitoring (King, 2007; King, Griffiths \& Williams, 2007). These changes, in addition to the rapid rise in the number of students and the transformation of higher education into a mass commodity, led countries all over the world to seek new models of governance that would make it possible to introduce order and efficiency in the academic world (McLendon et al., 2007).

\subsection{Models of Governance}

In their general form, models of higher education governance can be characterized based on three main features, according to Clark's (1983) triangle that describes the policy of higher education as mutual relations between market forces, the state, and academic oligarchy (see also: Olsen, 2007). The relative place accorded to each of these elements dictates the model of governance customary in a certain country. The models utilized in the different countries are not only a manifestation of current conceptions and popular practices (for example: mercantilism, universities as corporations) rather they are also rooted in the historical origins of the universities, particularly the Humboldtian and the Napoleonic traditions in Europe (Dobbins et al., 2010). In this paper we shall present the three main models according to the division suggested by Dobbins et al. (2011): the state-centered model, the self-rule model, and the market-oriented model. We shall also present case studies of countries that tend towards a certain model, as no country has embraced one single model absolutely to the exclusion of all others.

\subsubsection{The State-Centered Model}

This model is the most conservative in its regulatory approach, with schools of higher education perceived as public institutions operated by the state with the aim of meeting national goals. Research and teaching are perceived as products of the schools, contributing to the state's trade, industry, and technological capabilities and thus to society in general. In this model the state directly coordinates all aspects of higher education, including admission terms, determining candidacies, and acceptance of academic faculty, examinations, curricula, etc. Universities are strictly supervised and their administration controlled by the state and they are given very little autonomy. The state acts as a "gatekeeper" and has a direct impact on the university's internal affairs, particularly quality assurance, efficiency, and relationships with the business community (Dobbins et al., 2011). The state has a strong 
influence on research contents and on resource allocation. This model is characterized by a high degree of hierarchy, with academic faculty usually appointed rather than elected. The combination of uniform legislation and nationwide standards applied to schools of higher education creates strong ties between the universities and the government (Dobbins et al., 2011). At present, various countries tend towards this state-centered governance approach, for example: France, Sweden (Eurydice, 2008), Turkey (Mizikaci, 2006), and Russia (Panova, 2008).

\section{France (Note 5)}

The French system of higher education is very centralized and includes different types of institutions: 25 schools in the elitist sector (5\% of applicants are admitted), 78 universities, 113 university-affiliated vocational schools, and private schools for engineering and business administration (Kirsch, 2014). Government authorities reach decisions on essential issues such as staff recruitment, curricula, and budgeting. In the past, the Ministry of Education was the authority responsible for higher education as well as other fields of education. In 2007 the ministry was split and higher education and research were transferred to a separate ministry: "The Ministry of Higher Education and Research" (Ministère de l'Enseignement supérieur et de la Recherche). The Ministry of Higher Education encompasses 28 educational districts (académie) that operate as directorates of the universities.

The educational districts represent the Ministry of Higher Education and have a hierarchical and administrative role in the management, direction, and stimulation of higher education schools. They are responsible for conveying, applying, and integrating the instructions of the Ministry of Higher Education and for informing the ministry of the schools' activities. They coordinate between the schools in their district. The heads of the educational districts grant managing responsibilities to personnel within the schools, and transfer government investments as well as student scholarships. They are responsible for supervision and intervention within the schools' autonomy. They have a representative on each school's governing council and can ask the court to annul decisions reached within the schools. In addition, each district is responsible for managing the schools' property as well as their revenues and expenditures.

The schools are afforded autonomy through three councils that enable them to manage their internal affairs: the Managing Council, the Scientific Council, and the Student Council. Through these bodies, and particularly through the Managing Council, the institutions receive a certain amount of autonomy in three areas: in the financial area - managing funds allocated by the government; in the scientific-educational area - within the state's allocations for each study discipline, the school can determine contents, methods, and manners of evaluation; in the administrative area - the president who runs the university for a period of five years is elected by all councils of the institution and by all research and teaching units.

In addition to the educational districts, the Ministry of Higher Education also encompasses a National Committee for Higher Education and Research, which reaches decisions on the training, recruitment, and career course of faculty. The committee is composed of groups of disciplines, and each discipline has its own committee and divisions. At least two thirds of all 
division members are elected by colleagues and one third by the minister. All members are elected for a period of four years. The committee deals with matters pertaining to individual candidacies and promotion.

Furthermore, the minister responsible for higher education and research has advisory councils. The primary councils are the Higher Council for Education and the National Council for Curriculum. The councils are in charge of informing and advising the minister and the ministry on decisions pertaining to teaching, education, and faculty management. There are also advisory committees for research in charge of advising the minister on research policy and the planning of research budgets, as well as a National Council for Universities, which has a role in recruiting and awarding tenure to academic faculty at public universities. Opening new academic programs is the exclusive responsibility of the government. The French Higher Education Guideline Law (1984) states that in order to open a new academic program the school must receive government permission, and the latter determines the contents, duration of studies, and minimal number of hours required for each program. Academic programs may be launched without government approval, but these are not recognized by the French government and do not receive government funding.

\section{Sweden}

Sweden has 34 public academic institutions (14 research universities and 20 colleges), established following a Parliament resolution, and 17 private institutions that have government approval to grant academic degrees (of these, three are authorized to grant $\mathrm{PhDs}$ ). The structure of higher education governance is very centralized. There are two regulatory bodies, separated to a certain degree from the Parliament and the government; however governance is the main factor in decision making (Kirsch, 2014). The government, together with the Parliament, reaches decisions on the establishment of public colleges and universities, supported by Swedish law and regulations that enable a certain degree of government intervention in running academic schools and programs. In addition, two government authorities operate independently with the purpose of supervising higher education: The Swedish Higher Education Authority and The Swedish Council for Higher Education.

The Swedish Higher Education Authority is in charge of supervising higher education and responsible mainly for aspects of accreditation and quality control. The authority is charged with: accreditation of schools, degrees, and study programs; supervision of institutions of higher education through periodic monitoring and assessment; academic quality control; monitoring the efficiency of schools' internal management; updating teaching methods; determining administrative procedures for admission to academic institutions, and more. The authority is headed by the University Chancellor whose decisions are final and irreversible (Adkit, 2014). The authority's Advisory Council is comprised of four vice chancellors, a student representative, and a representative of local industry. The Advisory Council has no decision making powers, which belong to the chancellor.

The Swedish Council for Higher Education is the main administrative-planning body responsible for supervising procedures of academic applications and admissions; collecting 
and providing information to answer inquiries about nationwide schools; promoting collaboration between local institutions and colleagues all over the world; and recognizing degrees earned elsewhere. Members of the council are elected by the government and include ten members who represent the schools, the students, and local industry. Notwithstanding these bodies, the government and the Parliament are the primary decision makers with regard to Swedish higher education. They determine overall relevant goals and directives and they decide how resources shall be allocated. Eighty five percent of the higher education budget is governmental and its volume is determined by the government as part of its general budget. The Ministry of Education and Research is responsible for the budget. In 2011 Sweden enacted a government reform with the aim of strengthening the competitive edge of its academic institutions in the global market of higher education. The reform awarded institutions more autonomy in daily decisions such as the content of courses, terms of admission, and grade levels (Adkit, 2014).

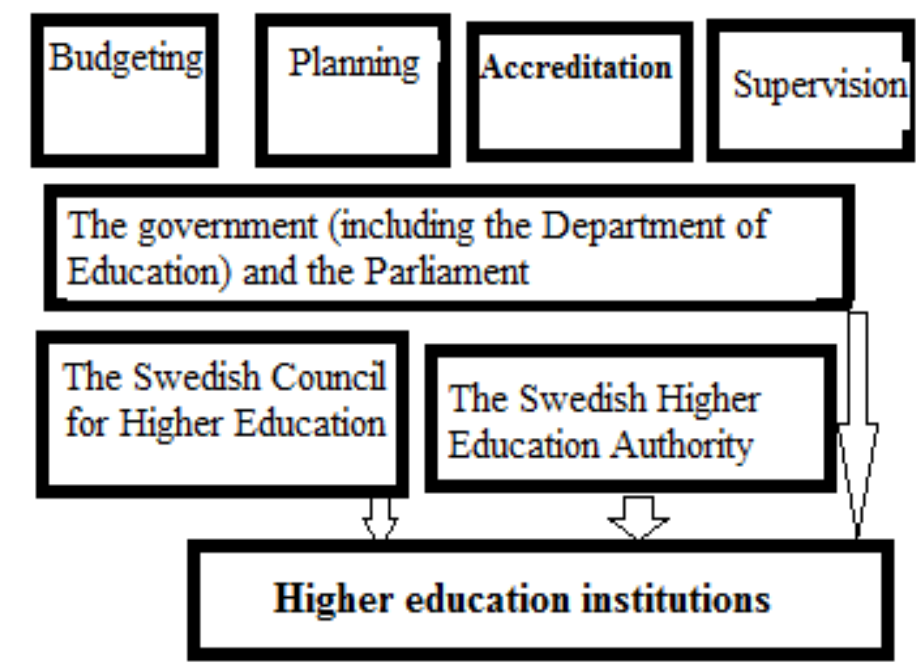

Figure 1. Structure of governance in Sweden (Note 6)

\subsubsection{The Self-Rule Model}

As stated above, the self-rule model derives from the freedom to learn and pursue research. In this approach, in contrast to the state-centered approach, the university is not a means of achieving external goals rather it is a goal in and of itself (Olsen, 2007). Research and learning have their own intrinsic value that is not necessarily compatible with national, public, or social interests. In the pure form of the Humboldtian model, academia receives budgeting from the state without being subjected to regulatory measures. Nonetheless, today even countries that espouse this model do not apply it in its utopic form rather restrict academic institutions through legislation and resource allocation. Universities have a high degree of autonomy, and the main feature of this style of governance is the lack of institutional coordination between the universities' strategies and political or industrial goals. Higher 
education is conducted with no plans for human resources. This model has a significant influence on the method of higher education governance in Germany, Austria, and several central European countries (Dobbins et al., 2011).

\section{Germany (Note 7)}

Germany's system of higher education is a binary system that distinguishes between two types of institutions: classic universities that grant degrees and institutions of higher education that grant a diploma that is not an academic degree (mainly universities for applied sciences - Fachhochschulen - as well as music schools and colleges). About two thirds of the German system is public and a third is private. Public universities are defined as "corporations that operate under the public law" and therefore faculty members are considered civil servants, degrees are government degrees, and student admission derives from national legislation. The universities' basic budget comes from the government. All academic institutions are subject to the Higher Education Framework Law (Hochschulrahmengesetz) and to the laws and regulations of their district (Länder). Germany has 16 districts, and each district has an office for higher education that governs the institutions under its jurisdiction. There are a wide range of laws and systems for managing higher education, with the general trend being to award institutions a high degree of autonomy. Most districts have integrated detailed government planning and regulation. The dominant approach in the districts is the steering approach, applied together with block grants, management contracts, and formula-based budgeting. The federal government lets institutions increase their budget by meeting competitive criteria of excellence in research and establishing graduate schools. Every school is entitled to one million euros a year and a grouping of excelling universities in a single district will entitle them to up to six million euros a year.

Every district has several areas of authority: ratifying the status of higher education institutions; regulating the institutional structure through laws of higher education and particularly faculty administration, budgets, and finance; approving studies and regulating exams; confirming rectors and presidents after their election; confirming professors. In several districts, some of the regulatory functions are awarded to university councils whose role is similar to that of a board of governors. Moreover, in some districts the entire faculty is employed and approved by the university presidents. In all districts the internal budget is managed independently by the institutions. The relatively small private sector in German higher education is funded by tuition and private funds, although in some cases the government does provide financial support. Private institutions are subject to local district regulation as well.

\section{UK}

The UK system of higher education includes three types of schools: universities, colleges, and research institutes. Universities deal with research and teaching; colleges focus mainly on teaching and award Bachelor's and Master's degrees (usually not research degrees); research institutes are a type of specialist university that awards advanced degrees (Adkit, 
2014). Higher education in the UK is private but maintains strong ties with the government (Eurydice, 2008). Different types of institutional charters reflect each school's tradition and background. Institutions that received the status of "university" after the 1992 legislation (Note 8) were restricted by the authority of institutional governance bodies, together with formal government provisions and documents prepared and approved by the Privy Council.

At schools recognized as universities prior to the 1992 legislation, governance is associated with the universities as determined in their charter. As a result, older British universities have a wide variety of governance styles, with essential differences particularly evident in their management. In post-legislation years, older universities operated as independent communities of scholars who continued to utilize the participatory method: university senates and their councils were large and conservative. Nonetheless, since the late 1990s it is possible to identify a gradual movement of these institutions towards an executive style of governance, similar to that customary at schools with post-1992 charters. The executive style of management has grown and is slowly replacing the participatory style (Eurydice, 2008).

All British institutions are subject to three regulatory agencies: The Higher Education Funding Council (HEFC); the Quality Assurance Agency for Higher Education (QAA); and the Privy Council. The HEFC is a non-departmental public body in charge of supervising public funds used for higher education and of distributing funding between the universities and the colleges. Budgeting takes both the form of core budgets and specific funding of special projects. This agency is also in charge of budgetary control; application and development of research-based policy; forging relationships between academic institutions and the community and business world; support of centers for excellence, and more. It consists of 12-15 members from the academia and industry, nominated by the Secretary of State for Innovation, Universities and Skills for a period of three years. The HEFC awards schools funds as block grants and institutions may distribute the grants as they see fit, so long as they are used for study and research activities (the council is entitled to stipulate conditions for a portion of the grant). The total budget for higher education is determined by the government. Within the budgetary framework, and according to distribution criteria appearing in the grant notice, the HEFCE board of directors in consultation with its staff decides on allocations for each specific institution and purpose. Most of the budgeting follows a set formula, such that the board of directors has relatively limited discretion. Nonetheless, the board does reach decisions as to implementation of certain government policies. Theoretically, it is possible to appeal the HEFCE's decisions in a court of law (Adkit, 2014).

The purpose of the QAA is to protect public interests by setting quality standards for higher education. This is done by holding periodic surveys of each school. Its main functions are: inspecting the quality of academic degrees and improving quality management in higher education by: holding external reviews; setting clear and uniform academic criteria; consulting the government on accreditation of degrees and institutions. This is an extra-governmental agency comprised of five departments, employing 110 workers and run by a board of directors. The board of directors includes 14 members with prior experience in 


\section{Macrothink}

Global Journal of Educational Studies

ISSN 2377-3936

2015, Vol. 1, No. 1

industry or in a relevant professional field, with 4 representing the heads of universities and colleges, 4 appointed by the HEFCE, and the rest appointed by the board of directors. Schools that do not meet HEFCE quality standards are subjected to a variety of sanctions, with the ultimate sanction being complete withdrawal of all government budgets (Adkit, 2014).

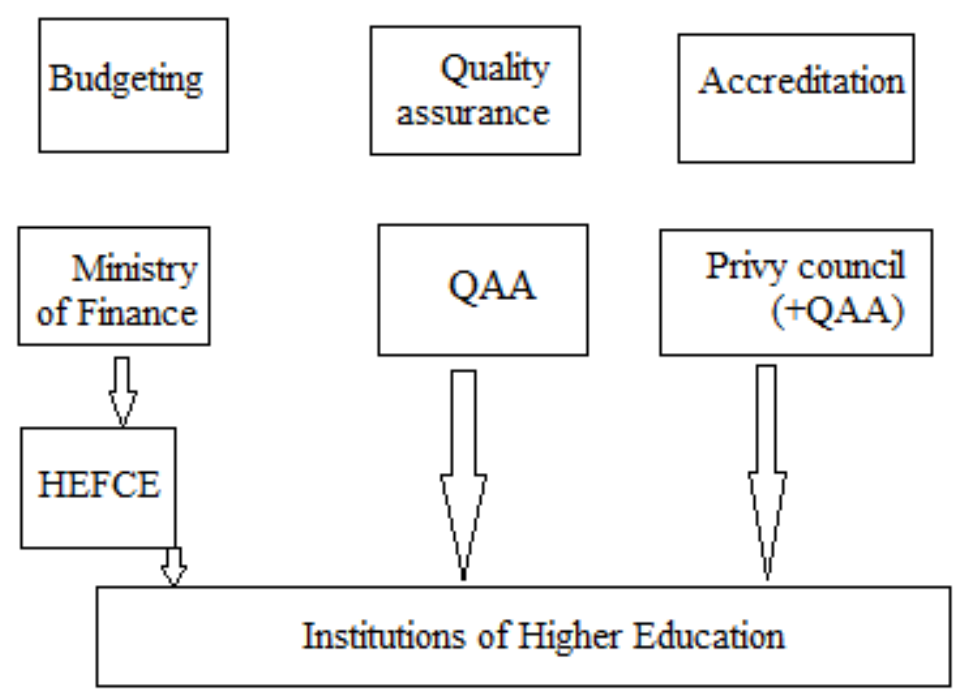

Figure 2. Structure of governance in the UK (Note 9)

\subsubsection{The Market-Oriented Model}

The underlying premise of governance tending towards the market-oriented model is that universities function more efficiently when they operate as financial corporations within local and global markets. The market-oriented model receives its inspiration from the capitalist approach, which assumes that organizations attain maximal efficiency in conditions of competition and a free market. In this model universities compete with each other for students and financial resources. University managers see themselves as entrepreneurs or manufacturers heading a corporation aimed at offering students academic services. The market-oriented model, sometimes also called the "entrepreneurial university" model, uses private industry's management principles of performance-based funding. The university is not a goal in and of itself and neither does it constitute public goods. Instead, the university is perceived as a commodity, an investment, and a strategic resource. The government does not take measures to design and plan the system of higher education; rather, it promotes competition and increases quality assurance and transparency in academic institutions. The assumption is that the competition between the schools ("vendors" or "providers") for students' ("buyers" or "consumers") support and money, may affect universities' decision making processes with regard to expenditures, the educational product, and institutional innovativeness and adaptation. 


\section{MInstitute Macrothink $^{m}$}

Global Journal of Educational Studies

ISSN 2377-3936

2015, Vol. 1, No. 1

Transforming higher education into a consumer good subject to the "invisible hand" of the free market might lead to privatization of the system. However the government can also be involved and influence higher education indirectly by encouraging competition and integrating quality assurance measures. Governments can choose to introduce a policy that encourages competition, for example by regulating financial support and integrating tools that affect the structure of pricing and enrollment in institutions of higher education. Thus, in this model the government's governance is manifested indirectly. In contrast to the state-centered model, which seeks to maneuver the higher education system by planning human resources and enacting regulations and laws, in the current model the government's intervention is manifested mainly in granting incentives to encourage competition and high standards.

\section{United States}

The United States has thousands of higher education institutions of different types, from two-year community colleges to world leading research universities. The number of students at the various schools consists of about $50 \%$ of the relevant age group. Of all the thousands of schools, only some 111 are research universities, and many universities seldom engage in research (Kirsch, 2014). The American structure of accreditation is not centralized recognition and quality control are performed by private non-profit organizations. Most US states award licenses to institutions and programs with no need for an accreditation process, however government grants for institutions and students are predicated on accreditation. The system is funded through two main channels - the federal channel and the state channel (Adkit, 2014). On the federal level most of the funds are devoted to support of research and the great majority of these funds are granted by two bodies: The National Science Foundation and The National Institutes of Health.

On the level of the individual state, supervision is performed by the regional government that supervises academic schools under its jurisdiction. For example, the State of Alabama has a Commission on Higher Education that supervises higher education. The commission is responsible for establishing new schools, approving academic programs, and developing higher education in the long term, and it does not intervene directly in the schools themselves. The commission consists of 22 members, appointed by the governor. Most are business people or prominent third sector activists (Student Association, 2014). The academic faculty and the students are not represented. In the State of Texas supervision is performed by the Higher Education Coordinating Board. The board consists of 22 members, appointed by the governor. Board members can be employees of an educational institution or members of the Board of Governors of an educational institution.

The State of California has a Board of Regents consisting of 26 members who are responsible for the public system of higher education. The board is in charge of distributing the budget and of appointing university presidents. Eighteen of the board's representatives are appointed by the state governor for a period of 21 years, one student representative is elected by the board, and 7 others are permanent members by virtue of their position (Note 10). Two faculty members are observers, with no voting rights (Student Association, 2014). The State 
of California is a distinct example of the market-oriented model. California's system of higher education includes three types of institutions: colleges (e.g., California State University), universities (e.g., University of California), and community colleges (e.g., California Community College). The institutions are subject to the regulation of five main bodies: the federal Department of Education; the Council for Higher Education Accreditation; private accreditation agencies; boards of directors at institutions of higher education (in the three sectors); and the California Bureau for Private Postsecondary Education. The federal budget is utilized mainly (80\%) for research purposes, while the state budget is allocated for teaching by the governor (the Treasury) and approved by the legislator. In addition, each school has its own budget. In principle, the budgets transferred to the universities and colleges are not significantly supervised. They are transferred by the State Treasury as a block grant and the institutions are entitled to decide on their use. Community colleges have stricter supervision since their funding is based on the state budget (Adkit, 2014).

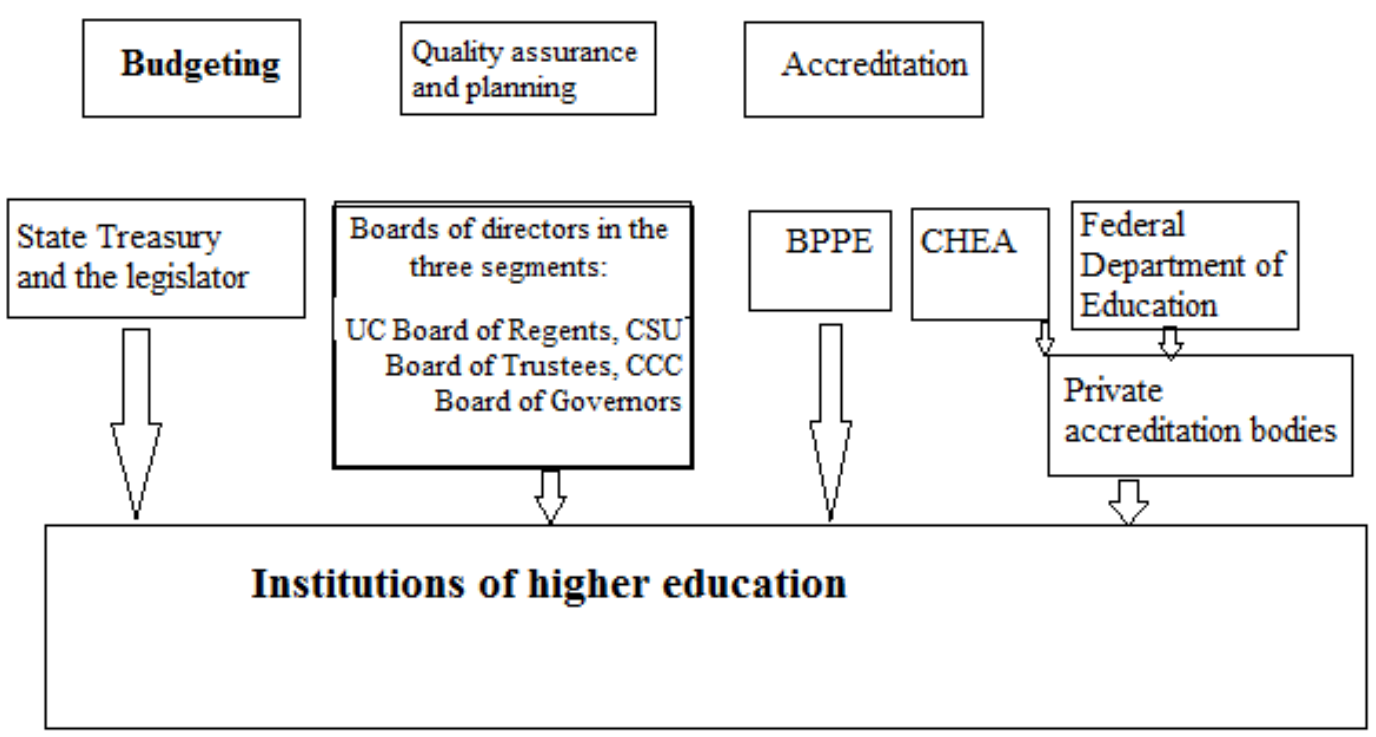

Figure 3. Structure of governance in the US (Note 11)

\section{Australia}

Higher education in Australia is a considerable industry with high profits. In 2012 the country's institutions of higher education recorded profits of more than 26 billion dollars (Norton, 2014). Australia has over one million students, of whom a quarter are foreign students. Fifteen percent of university budgets come from the tuition of these international students (Kirsch, 2014). Schools of higher education include private and public schools that operate under federal and territory law (Breen, 2002). As of 2014, there were 43 universities and some 130 non-university postsecondary schools (vocational schools, colleges). Unlike non-university schools, universities must be registered and must comply with standards set by the Tertiary Education Quality and Standards Agency: TEQSA). TEQSA is in charge of 
making sure that all such institutions are licensed to operate as a university and meet the terms of the federal government (Australian Qualification Framework: AQF). These rules determine the type and nature of training that the school is qualified to provide (Note 12).

Australia's Government Department of Education, in charge of higher education, operates under TEQSA's legislation and standards. The department is responsible for allocating research and teaching budgets to each university (as a block grant). According to TEQSA legislation, the Associate Secretary for Higher Education implements higher education policy and sets threshold conditions for higher education providers, under legislation termed the Higher Education Standards Framework (HESF, 2011). These criteria refer to aspects of registration, accreditation of courses and training, and are determined by a group of experts. This group, called the Higher Education Standards Panel (HESP), is appointed by the Government Minister for Education and is in charge of development and of advising the minister on the contents of the said criteria. Before accepting and setting the criteria the minister is required to consult with the Territory Ministers for Education and with TEQSA. From the time the criteria are determined they give the Government Minister for Education a fairly large amount of authority. The minister has more power over the universities than the Chief Ministers of the territories and he is not subject to the restrictions of government legislation.

The universities, on their part, do not require approval for accreditation of courses, and they may decide these matters themselves as part of their academic freedom. The university Academic Board usually approves the opening of new courses and their contents and is not subject to any external supervision. The universities are subjected to regulation; however their legal structure reflects a style of internal self-governance and autonomy (Norton, 2014). Most Australian universities were indeed established by the government; however they are not considered means for realizing public-government goals. Territory Ministers for Education have no direct operative effect on the universities, and most of the supervision is manifested in terms stipulated for receiving financial grants. In practice, universities receive the terms and the funds from the government, however in theory they can reject both. Eligibility for government funding, in its various forms (Note 13), depends on the government's categorization of the university. For example, universities in category " $A$ " are entitled to all types of funding. These are mainly public universities in which the government appoints a board or senate members on its behalf. Universities in category "B" are eligible for research funding only (Note 14).

\section{Research Methodology}

This study utilizes a comparative methodology. Based on data from the Israeli Council for Higher Education and document and protocol analysis, a characteristic model of the specific Israel case was constructed. The strengths and weaknesses of each model are discussed, as well as the future of Israeli governance in light of local winds of change and global trends. Higher education in Israel emerged before the establishment of the state and with no formal governmental guidelines. The founding of the state in 1948 and the many changes and transitions that emerged since then generated new processes evident in higher education 
governance. These are examined in this study from a comparative perspective.

\section{Research Findings and Results: Governance in Israel - Current State (Note 15)}

In Israel there are 66 institutions of higher education: 7 research universities (Note 16), the Weizmann Institute (for advanced studies only), the Open University, 37 academic colleges (of these, 19 are government funded and 18 extra-budgetary), and 21 academic colleges of education. All institutions, including the Open University, have a total of over 300,000 students (CHE, 2014). The higher education budget totaled NIS 9 billion in 2014 (Student Association, 2013). The agencies responsible for maintaining a balance between academic freedom and supervision of higher education are: The Council for Higher Education (CHE) and The Planning and Budgeting Committee (PBC). These are responsible for all academic, administrative, and financial aspects of higher education. Furthermore, the CHE and the PBC, the agencies directly in charge of the system of higher education, have a certain responsibility for the activity and functioning of schools of higher education (Student Association, 2014).

First established was the CHE, which began its operations in the late 1950s under the Council for Higher Education Law (1958). This law determined that matters of higher education would be under the purview of an independent agency that will formulate policy and reach decisions following professional deliberations. The law states that the autonomy of institutions of higher education to manage their internal affairs would be retained in the form of budgets. Furthermore, the law states that at least two thirds of the council's members would be elected based on their personal status in the field of higher education. The number of members would range from 19-25, and the council would be headed by the current Minister of Education. Members are elected for a period of five years and must endeavor to realize the goals of the $\mathrm{CHE}$ and its responsibilities.

The responsibilities of the CHE are in three main areas: Accreditation: Recognition of academic institutions and degrees, supervision of recognized degrees; licensing of foreign branches; recognition of degrees awarded by the Judea and Samaria CHE. Planning: Proposals concerning the current institutions and their collaboration; proposals for research promotion; proposals for establishment of additional institutions and proposals concerning government participation in the schools' budgets. Other areas of responsibility: Use of protected titles such as university, technion, etc; maintaining a support system for students. In addition, as of 2003 the CHE operates a quality assessment system that performs periodic assessment of existing disciplines.

The PBC was established several years after the CHE. An amendment to the CHE Law (article 3e), together with enactment of Regulations of the Council for Higher Education (1975), led to establishment of a committee responsible for determining the higher education budget and submitting it to the government for approval. In Resolution 666 the government authorized the PBC to serve as an independent agency to mediate between the government and national institutions on the one hand and higher education institutions on the other in all budgetary matters. The PBC is responsible for proposing an unbiased higher education budget in consideration of social and national needs; determining the distribution of regular and development funds between the various institutions (Note 17); submitting proposals to 


\section{Macrothink}

Global Journal of Educational Studies

ISSN 2377-3936 2015, Vol. 1, No. 1

the government and the CHE concerning development plans and options for funding them; monitoring efficient utilization of the budget; consulting the CHE on opening new institutions or new units in current institutions. The committee is comprised of seven members, including the chairman, five of whom are from the academic world and the rest public representatives from economic fields. Members of the committee are appointed by the Minister of Education, with the consent of the Chairman of the PBC and approval of the CHE. Appointments are made for three years with an option of extension for another three years.

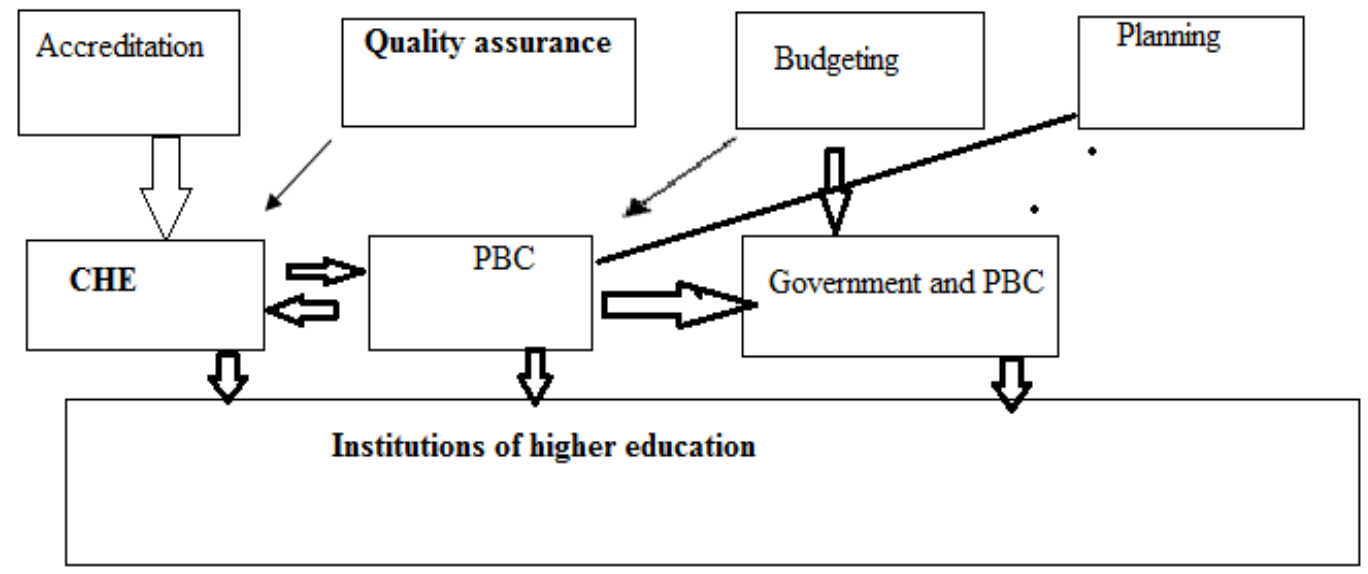

Figure 4. Structure of governance in Israel

\section{Models of governance - between the optimal and the actual}

Each of the governance models has advantages and disadvantages. In the classic model where the academic community manages its affairs independently, academic freedom and autonomy in research and teaching are maintained. Academia becomes immune to external influences. Countries tending towards this approach do not enforce means of planning and coordinating higher education. Moreover, freedom of management may clash with public interests, which justify and fund most public academic institutions. The centralized model includes more planning and control, the quality of higher education is highly supervised, and public interests are maintained. Then again, strict supervision does not allow for academic freedom and the freedom to pursue research. The government might restrict academic vision and prevent the development of areas that do not suit its interests.

With regard to the market-oriented model, its advantages are encouragement of competition, excellence, and innovativeness. Accordingly, some claim that since US universities are world leading institutions in all fields (Kirsch, 2014) this model has proven itself the most efficient. It too, however, has its limitations. Leaving higher education at the mercy of market forces might lead to the disappearance of less popular or less profitable areas. Moreover, as in the case of the US, higher education at top universities is very expensive (Note 18). Tuition for a 
Bachelor's degree can reach nearly fifty thousand dollars a year. (Note 19) Hence, this system of higher education is indeed outstanding and innovative but it is also intended for the rich only and does not afford the social mobility that higher education is supposed to provide.

The Israeli model of governance in its current format tends towards the classic model, with control, planning, accreditation, and budgeting determined by two independent bodies mostly comprised of senior academic faculty. This model is similar to the previous model utilized in the UK until 1992. At the time, the UK had a University Grants Committee, comprised of representatives of the schools and public officials and responsible for consulting the government on distribution of the higher education budget. At present, the global trend in countries espousing the model of an autonomous community of scholars is to support government supervision and control. As a result, it is possible to discern adequate representation in the committees and councils responsible for higher education in these countries. In Israel the dominant form of governance, as anchored in legislation in the country's initial years, supports autonomous and independent management of higher education "while giving a wide interpretation to the concept of academic freedom and government inability to act as a functioning regulator" (Student Association, 2014, p. 8).

At present, now that capitalism is not only an economic theory rather also a social approach, allegations of the classic model's inefficiency are growing. Recently, a list of articles and position papers calling for reexamination of the Israeli model of governance have been published (see for example: Carmon, Dagan, \& Kremnitzer, 2014; Kirsch, 2014; Student Association, 2014). Some claim that it is necessary to increase the government's role in higher education governance, while others are in favor of opening higher education to competition and market forces and reducing the power of the political and government element. The debate reached government levels and a Committee for Arranging the Governance of Higher Education was appointed. The main goal of the committee, as formulated in its letter of appointment, was to reshape the organizational structure of the bodies in charge of managing higher education, such that their interface with the government would proclaim a relationship "devoted to maintaining autonomy in higher education, while also expressing government policy and national needs and goals" (Report of the Committee, 2014).

In its final report, the committee recommended among other things: establishing an Authority for Higher Education, and separating accreditation from the new Authority for Higher Education; including a student representative in the new Planning and Budgeting Committee; retaining the Minister of Education as chairman of the governance authority and appointing members of the various committees by a committee headed by a former Supreme Judge. Some claim that these changes, and particularly retaining the Minister of Education as head of the governance authority despite being a political nomination, might transform the government's involvement in the authority into one of control (Procaccia, 2014). In light of these recommendations, Israel's model of governance seems to be heading away from the market-oriented model and towards the regulatory model customary in European countries. 
Council for Higher Education

(CHE)

Headed by the Minister of Education
Planning and Budgeting Committee

Authority anchored only in a government resolution

According to the recommendations

Establishment of an Authority for Higher Education to be comprised of three bodies:

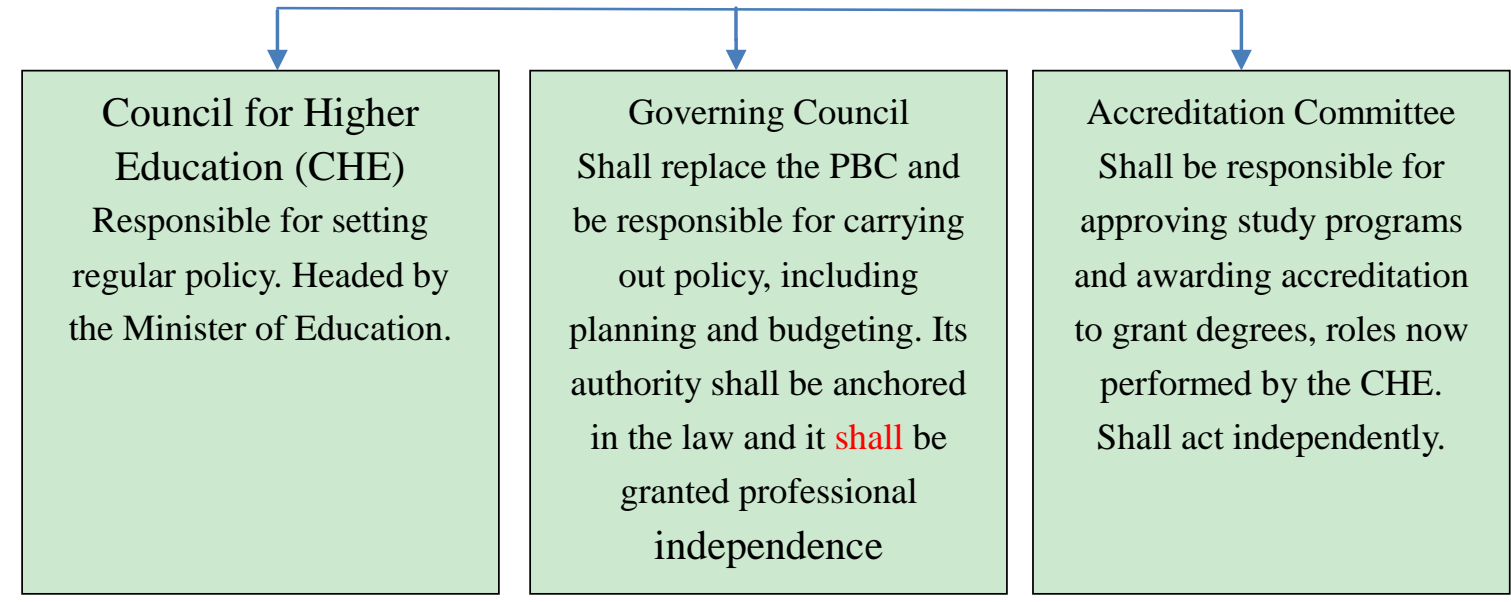

Figure 5. The current situation

\section{Conclusions}

The topic of higher education governance refers to the legal allocation of power in decision making within the university between the various governance structures and administrative structures. The purpose of higher education governance is to articulate the common public interest and realize its goals, while setting the boundaries of authority in theory and in practice - who shall decide and what is at the focus of decisions. In this paper we reviewed the topic of governance in theory and in practice from the late $19^{\text {th }}$ century until the early 1950s. The literature review and the various models of governance show that in the past universities were free to act and conduct themselves according to their own standards without bowing to the needs or demands of a funding government. At the same time, the emergence of capitalism in academia beginning from the twentieth century created new models of governance, with the aim of increasing order and efficiency in academia. In this paper we have charted the different styles of governance utilized around the world, versus Israel, according to three main models and according to the mutual relations between market forces, the state, and academic oligarchy.

\section{The models}

State-centered model- This model is the most conservative in its attitude to regulation, with institutions of higher education perceived as public institutions operated by the state in order to meet national goals. Universities are strongly supervised and their administration controlled by the state and they are given very little autonomy, for example: France, Sweden, 
Turkey, and Russia.

Self-rule model - This model stems from the principle of freedom to study and pursue research. In this approach, in contrast to the state-centered approach, the university is not a means of achieving external goals rather a goal in and of itself. Research and study have their own intrinsic value that is not necessarily compatible with national, public, or social interests, such as the Humboldtian model in Germany. We saw that at present the primary feature of this type of governance is a lack of institutional coordination between the universities' strategies and political or industrial goals. Higher education conducts itself with no plans concerning human resources, for example in Germany, Austria, and several central European countries.

Market-oriented model - This model is inspired by the capitalist approach, which assumes that organizations reach maximal efficiency in a state of competition and a free market. In this model universities compete with each other for students and financial resources. Directors or heads of universities see themselves as entrepreneurs or manufacturers heading a corporation whose aim is to offer students academic services. The university is not a goal unto itself and neither is it public goods. Instead, the university is perceived as a commodity, an investment, and a strategic resource. The government does not take measures to design and plan higher education; rather, it promotes competition and increases quality assurance and transparency in institutions, as in the US and Australia.

In summary, this study points to a trend that might result in the privatization of higher education. The question is: Will this harm efforts to increase the accessibility of higher education - a policy reflecting the value of equality in higher education? Will the option of opening a "university" be open to all organizations? What are the "red lines" of market forces?

Today, when capitalism represents a socioeconomic conception, allegations of the classic model's inefficiency are growing, and some are in favor of reexamining the Israeli model of governance. There are those who claim that it is necessary to increase the government's role in higher education governance, while others support opening higher education to competition and market forces and reducing the power of the political and government element. Hence, the government appointed a committee for arranging the governance of higher education. The purpose of the committee was to suggest a new organizational structure for the agencies in charge of managing higher education. This structure is expected to form an interface reflecting the relationship between agencies protecting the autonomy of higher education, while also expressing government policy and national needs and goals.

The committee recommended supporting the first model, in which the government remains a major player: establishing an Authority for Higher Education, and separating accreditation from the new Authority for Higher Education; including a student representative in the new Planning and Budgeting Committee; appointing the Minister of Education as chairman of the governance authority and appointing members of the various committees by a committee headed by a former Supreme Judge. In light of these recommendations, Israel's model of governance seems to be heading away from the market-oriented model and approaching the regulatory model customary in European countries, with the state occupying a central role in 
higher education governance.

Does the state want a major role in higher education governance, is it capable of and committed to upholding it? To what degree, in our capitalist era, with one third of the students enrolled in private institutions, is the state capable of curbing market forces?

Can the state continue its dual policy within the self-rule principle, espousing both regulation and privatization? For how long? Does the process of quality assessment initiated by the CHE about ten years ago constitute part of the government's capitalist policy - whereby the strong, in the qualitative meaning of the word, shall prevail? Will the government continue to maneuver the system of higher education by providing incentives to encourage competition and high standards?

\section{References}

Adkit - International Information and Research (2014). Higher education - regulatory models in the world - international review. Retrieved from http://www.che.org.i1/wp-content/.../2014/01.pdf

Amaral, A. (2009). Recent trends in European higher education. Reforms and Consequences in Higher Education Systems: An International Symposium. Hitotubashi Chiyoda-ku, Tokyo: National Center of Sciences.

Boer, H., \& File, J. (2009). Higher education governance reforms across Europe. Centre for Higher Education Policy Studies (CHEPS).

Bradley, D., Noonan, P., Nugent, H., \& Scales, B. (2008). Review of Australian higher education: Final report. Retrieved from http://www.voced.edu.au/content/ngv32134

Bridges, D., Juceviciene, P., Jucevicius, R., Mclaughlin, T. H., \& Stankeviciute, J. (2014). Higher education and national development: Universities and societies in transition. Routledge.

Breen, J. (2002). Higher education in Australia: Structure, policy and debate. Monash University. Retrieved from http://www.csse.monash.edu.au/ jwb/aused/aused.html

Carmon, A., Dagan, H., \& Kremnitzer, M. (2014). Arrangement of the governance of higher education in Israel: Challenges and recommendations. Retrieved from http://www.haaretz.co.il/opinions/.premium-1.2335491

Clark, B. R. (1983). The higher education system. Berkeley: University of California Press.

Cobban, A. B. (1992). Reflections on the role of medieval universities in society. In Smith \& B. Ward (Eds.), Intellectual life in the middle ages (pp. 227-241). London: Hambledon Press.

Commager, H. S. (1963). The university and freedom: "Lehrfreiheit" and "Lehrnfreiheit". The Journal of Higher Education, 361-370. http://dx.doi.org/10.2307/1980014

Corcoran, S. (2004). Duty, discretion and conflict: University governance and the legal obligations of university boards. Australian Universities' Review, 46(2), 30-37. 


\section{Macrothink}

Global Journal of Educational Studies ISSN 2377-3936

Council for Higher Education. (2014). Israel's system of higher education. Retrieved from http://che.org.il/?page_id=399

De Boer, H., Huisman, J., \& Meister - Scheytt, C. (2010). Supervision in 'modern' university governance: Boards under scrutiny. Studies in Higher Education, 35(3), 317-333. http://dx.doi.org/10.1080/03075070903062849

Dobbins, M., \& Knill, C. (2014). Higher education governance and policy change in Western Europe: International challenges to historical institutions. Palgrave Macmillan. http://dx.doi.org/10.1057/9781137399854

Dobbins, M., \& Knill, C. (2009). Higher education policies in Central and Eastern Europe: Convergence toward a common model? Governance, 22(3), 397-430. http://dx.doi.org/10.1111/j.1468-0491.2009.01445.x

Dobbins, M., Knill, C., \& Vögtle, E. M. (2011). An analytical framework for the cross-country comparison of higher education governance. Higher Education, 62(5), 665-683. http://dx.doi.org/10.1007/s10734-011-9412-4

Enders, J. (2004). Higher education, internationalisation, and the nation-state: Recent developments and challenges to governance theory. Higher Education, 47(3), 361-382. http://dx.doi.org/10.1023/B:HIGH.0000016461.98676.30

Ferlie, E., Musselin, C., \& Andresani, G. (2008). The steering of higher education systems: A public management perspective. Higher Education, 56(3), 325-348. http://dx.doi.org/10.1007/s10734-008-9125-5

Finnie, R., \& Usher, A. (2007). Room at the top: Strategies for increasing the number of graduate students in Canada. PLACE: C.D. Howe Institute.

Gal Nur, Y. (2009). Higher education in distress. Alpayim, 34, 130-147.

Graham, H. D. (1989). Structure and governance in American higher education: Historical and comparative analysis in state policy. Journal of Policy History, 1(1), 80-107. http://dx.doi.org/10.1017/S0898030600004607

Guri, R. S. (2005). University: Its ideological origins and varied manifestations. In A. Gur Zeev (Ed.), End of Israel's academia? (pp. 23-68). Haifa: Haifa University, Department of Education.

Haskins, C. H. (1957). The rise of universities. Ithaca, NY: Cornell University Press.

Higher Education Standards Framework. (2011). Retrieved from http://www.comlaw.gov.au/Details/F2013C00169

Kaiser, F. (2007). Higher education in France: Country report. Retrieved from http://doc.utwente.nl/59793/1/2007countryreportfrance.pdf

Kezar, A. J., \& Eckel, P. D. (2004). Meeting today's governance challenges: A synthesis of the literature and examination of a future agenda for scholarship. The Journal of Higher 
Education, 75(4), 371-399. http://dx.doi.org/10.1353/jhe.2004.0022

King, R. (2007). Governance and accountability in the higher education regulatory state. Higher Education, 53, 411-430. http://dx.doi.org/10.1007/s10734-005-3128-2

King, R., Griffiths, P., \& Williams, R. (2007). Regulatory intermediation and quality assurance in higher education: The case of the auditors. Oxford Review of Education, 33, 161-174. http://dx.doi.org/10.1080/03054980701259790

Kirsch, U. (2014). The higher education system in Israel - Issues, characteristics, and unique aspects. Jerusalem: Shmuel Ne'aman Institute.

Lindberg, M. (2007). At the frontier of graduate surveys: Assessing participation and employability of graduates with master's degree in nine European countries. Higher Education: The International Journal of Higher Education and Educational Planning, 53, 623-644. http://dx.doi.org/10.1007/s10734-005-1672-4

McLendon, M. K. (2003). State governance reform of higher education: Patterns, trends, and theories of the public policy process. In J. C. Smart (Ed.), Higher education: Handbook of theory and research (Vol. XVIII, pp. 57-143). Netherlands: Springer. http://dx.doi.org/10.1007/978-94-010-0137-3_2

McLendon, M. K., Deaton, S. B., \& Hearn, J. C. (2007). The enactment of reforms in state governance of higher education: Testing the political instability hypothesis. The Journal of Higher Education, 78(6), 645-675. http://dx.doi.org/10.1353/jhe.2007.0041

Meek, V. L. (2002). On the road to mediocrity? Governance and management of Australian higher education in the market place. In A. Amaral, G. Jones, \& B. Karseth (Eds.), Governing higher education: National perspectives on institutional governance (pp. 235-260). Netherlands: Springer. http://dx.doi.org/10.1007/978-94-015-9946-7_12

Mizikaci, F. (2006). Higher education in Turkey. UNESCO-CEPES. Monographs on Higher Education. Retrieved from http://www.unesdoc.unesco.org/images/0014/001455/145584e.pdf

National Student Association. (2014). Position of the student association on the committee for governance of Israeli higher education. Retrieved from http://www.nuis.co.il

Neave, G. (2003). The Bologna Declaration: Some of the historic dilemmas posed by the reconstruction of the community in Europe's systems of higher education. Educational Policy, 17(1), 141-164. http://dx.doi.org/10.1177/0895904802239290

Norton, A. (2012). Mapping Australian higher education. Carlton, Victoria, Australia: Grattan Institute. $\quad$ Retrieved from http://grattan.edu.au/wp-content/uploads/2014/10/816-mapping-higher-education-2014.p df

Olsen, J. (2007). The institutional dynamics of the European University. In M. Peter, \& O. Johan (Eds.), University dynamics and European integration. Dordrecht: Springer. 
http://dx.doi.org/10.1007/978-1-4020-5971-1_2

Panova, A. (2008). Governance structures and decision making in Russian higher education institutions. Problems of Economic Transition, 50(10), 65-82. http://dx.doi.org/10.2753/PET1061-1991501004

Pennock, L., Jones, G. A., Leclerc, J. M., \& Li, S. X. (2015). Assessing the role and structure of academic senates in Canadian universities, 2000-2012. Higher Education, 1-16. http://dx.doi.org/10.1007/s10734-014-9852-8

Procaccia, U. (2014). Basic principles for constructing the governance authority of higher education. $4^{\text {th }}$ Conference on Higher Education. Retrieved from http://che.org.il/wp-content/uploads/2014/05/\%D7\%9E\%D7\%A2\%D7\%A8\%D7\%9B\% D7\%AA-\%D7\%94\%D7\%94\%D7\%A9\%D7\%9B\%D7\%9C\%D7\%94-\%D7\%94\%D7\%9 2\%D7\%91\%D7\%95\%D7\%94\%D7\%94-\%D7\%91\%D7\%99\%D7\%A9\%D7\%A8\%D7\% 90\%D7\%9C-2014.pdf

Readings, B. (1996). The university in ruins. Cambridge, MA: Harvard University Press.

Report. (2014). Committee for arranging the governance of higher education.

Rowlands, J. (2013). Academic boards: Less intellectual and more academic capital in higher education governance? Studies in Higher Education, 38(9), 1274-1289. http://dx.doi.org/10.1080/03075079.2011.619655

Salter, B., \& Tapper, T. (2013). The state and higher education: State \& higher education. Routledge.

Schechter, S. (2006). Cracks in the ivory tower. Jerusalem: Tzivonim.

Scott, J. (2006). The mission of the university: Medieval to postmodern transformations. Journal of Higher Education, 77, 1-39. http://dx.doi.org/10.1353/jhe.2006.0007

Solanke, O. A. (2011). Models of institutional culture and governance: A literature review. Hummingbird, 2, 69-76.

Toutkoushian, R., \& Shafiq, M. M. (2010). A conceptual analysis of state support for higher education: Appropriations versus need-based financial aid. Research in Higher Education, 51(1), 40-64. http://dx.doi.org/10.1007/s11162-009-9148-5

Vaira, M. (2004). Globalization and higher education organizational change: A framework for $\begin{array}{llll}\text { analysis. Higher } & \text { Education, } & 48(4) . & 483-510 .\end{array}$ http://dx.doi.org/10.1023/B:HIGH.0000046711.31908.e5

Zimmerman. (2005). Concept of the university, science, and the state from a historical perspective. In A. Gur Zeev (Ed.), End of Israel's academia? (pp. 69-91). Haifa: Haifa University, Department of Education. 


\section{Notes}

Note 1. On the main structural reforms in US states see Appendix 1 (from: McLendon, 2003).

Note 2. An indication of the significance of this issue and its role as part of Israel's agenda is the 2013 government decision to appoint a committee to examine the regularization of Israel's higher education governance. The committee's report was published in full in July 2014.

Note 3. The name "university" originates from Medieval Latin - universities, meaning guild.

Note 4. These principles were manifested in the approach assuming that students would be trained for a life of research and that intellectually and mentally students are mature people with a wide education. Therefore, lecturers were perceived first and foremost as research workers rather than as teachers or knowledge mediators (Iram, 1983).

Note 5. Based on Kaiser, 2003.

Note 6. From: Adkit, 2014.

Note 7. Based on: Higher Education Finance and Cost-Sharing in Germany. http://gse.buffalo.edu/org/inthigheredfinance/files/Country_Profiles/Europe/Germany.pdf

Note 8. Further and Higher Education Act, 1992.

Note 9. Adkit, 2014.

Note 10. The Governor, Lieutenant Governor, Chair of the California Senate, Superintendent of California's Department of Education, President and Vice President of the University of California Alumni Associations, and President of the University of California.

Note 11. Adkit, 2014.

Note 12. Training levels range from one to ten. A Bachelor's degree, for example, is considered level 7, see Appendix 2.

Note 13. For the various forms of funding offered by the government see Appendix 3.

Note 14. For the full list of categories see Appendix 4.

Note 15. Based on the Report of the Committee for Arranging the Governance of Higher Education (2014).

Note 16. The CHE presents the data on the Ariel University as part of the academic colleges, in order to maintain data consistency and to enable comparison between the years presented in the data collection.

Note 17. In 1995 the CHE Law was amended once again and article 17a added: "The state's budgeting of government-funded higher education institutions and academic colleges shall follow equal standards that shall be determined, among other things, in consideration of issues pertaining to the institutions and development, teaching, and research plans approved by the council, any of its committees authorized to do so, or the Ministry of Education, Culture, and Sports, as the case may be."

Note

18.

See

http://www.topuniversities.com/student-info/student-finance/how-much-does-it-cost-study-us 
Note

http://www.topuniversities.com/student-info/student-finance/tuition-fees-world\%E2\%80\%99 s-top-universities

Note 20. From McLendon, 2003.

\section{Appendix 1. Reform in the structure of higher education governance in US states (Note} 20)

Table 2.1: State Restructuring Initiatives Enacted 1991-2001

\begin{tabular}{|c|c|c|c|}
\hline $\begin{array}{l}\text { Year of } \\
\text { Enactment }\end{array}$ & State & Nature of Reform & Data Source \\
\hline 1991 & Massachusetts & $\begin{array}{l}\text { Consolidated two separately governed } \\
\text { state universities under a reconstituted } \\
\text { University of Massachusetts system; } \\
\text { replaced the Board of Regents, a } \\
\text { consolidated governing board, with a } \\
\text { coordinating board; delegated much of the } \\
\text { authority of the former Board of Regents } \\
\text { to the University of Massachusetts, } \\
\text { including authority over tuition and } \\
\text { collective bargaining; created cabinet } \\
\text { position of secretary of education. }\end{array}$ & $\begin{array}{l}\text { Crosson, 1996; } \\
\text { Marcus, } 1997\end{array}$ \\
\hline 1991 & Minnesota & $\begin{array}{l}\text { Merged three previously separate } \\
\text { systems - a state university, a community } \\
\text { college system, and a technical college } \\
\text { system - under a new consolidated board, } \\
\text { indirectly reducing the scope of authority } \\
\text { of the coordinating board. }\end{array}$ & $\begin{array}{l}\text { MacTaggart, } \\
\text { 1996; } \\
\text { Marcus, } \\
1997\end{array}$ \\
\hline 1992 & Maryland & $\begin{array}{l}\text { Reorganized the University of Maryland } \\
\text { system, granting the Board of Regents of } \\
\text { the system greater authority; exempted } \\
\text { St. Mary's College from the U-M system } \\
\text { and from most state procedural controls; } \\
\text { established a separate governing board for } \\
\text { the college; converted state appropriation } \\
\text { for the college from line-item to lump-sum. }\end{array}$ & Berdahl, 1998 \\
\hline 1993 & Arizona & $\begin{array}{l}\text { Replaced a single statewide governing } \\
\text { board with three separate boards for the } \\
\text { state university and community college } \\
\text { systems. }\end{array}$ & Marcus, 1997 \\
\hline 1994 & Montana & $\begin{array}{l}\text { Restructured state governance of the six } \\
4 \text {-year campuses and the five 2-year } \\
\text { vocational institutions, which previously } \\
\text { reported to the Commission of Education } \\
\text { office. The initiative created a } \\
\text { coordinating board to which both the } \\
\text { University of Montana ( } 6 \text { institutions) and } \\
\text { Montana State University (5 institutions) } \\
\text { systems report. }\end{array}$ & $\begin{array}{l}\text { Marcus, 1997; } \\
\text { McLendon } \\
\text { and Ness, } \\
2001\end{array}$ \\
\hline 1994 & New Jersey & $\begin{array}{l}\text { Replaced the New Jersey Board of } \\
\text { Higher Education, a strong regulatory } \\
\text { coordinating board, with a considerably } \\
\text { weaker commission; delegated authority } \\
\text { over new academic programs and tuition } \\
\text { setting directly to local campuses; created } \\
\text { a Presidents Council to make } \\
\text { recommendations about institutional } \\
\text { planning, budgeting \& program approval. }\end{array}$ & $\begin{array}{l}\text { Brown, 1998; } \\
\text { Greer, 1998; } \\
\text { Marcus, 1997; } \\
\text { Marcus, 1997; } \\
\text { McGuinness, } \\
\text { 1995; } \\
\text { Novak, } 2000\end{array}$ \\
\hline
\end{tabular}




\begin{tabular}{|c|c|c|c|}
\hline $\begin{array}{l}\text { Year of } \\
\text { Enactment }\end{array}$ & State & Nature of Reform & Data Source \\
\hline 1995 & Illinois & $\begin{array}{l}\text { Replaced two regional multicampus } \\
\text { governing boards with individual boards } \\
\text { for seven of the eight campuses under the } \\
\text { two systems and delegated authority of } \\
\text { the former systems to the new campus } \\
\text { boards. }\end{array}$ & $\begin{array}{l}\text { Marcus, 1997; } \\
\text { McLendon, 2000a; } \\
\text { McLendon } \\
\text { and Ness, 2001; } \\
\text { Van Der Slik, } 1998\end{array}$ \\
\hline 1995 & Minnesota & $\begin{array}{l}\text { In the spirit of the state's } 1991 \text { act, } \\
\text { replaced the Higher Education } \\
\text { Coordinating Board with a less powerful } \\
\text { Higher Education Services Office. }\end{array}$ & $\begin{array}{l}\text { Marcus, 1997; } \\
\text { McLendon and } \\
\text { Ness, } 2001\end{array}$ \\
\hline 1995 & Oregon & $\begin{array}{l}\text { Converted the State System of Higher } \\
\text { Education from traditional state agency } \\
\text { status to that of "semi-independent state } \\
\text { agency" with authority to manage certain } \\
\text { day-to-day fiscal and procedural } \\
\text { operations independent of the central state } \\
\text { administrative authority. }\end{array}$ & $\begin{array}{l}\text { Underwood, 1999; } \\
\text { McLendon and } \\
\text { Ness, } 2001\end{array}$ \\
\hline 1995 & $\begin{array}{l}\text { South } \\
\text { Carolina }\end{array}$ & $\begin{array}{l}\text { Altered the size, structure, and } \\
\text { responsibilities of the Commission of } \\
\text { Higher Education; restructured the } \\
\text { commission to shift control from the } \\
\text { Executive Director to individual } \\
\text { institutions (primarily the } 3 \text { research } \\
\text { institutions-Clemson, USC, MUSC) by } \\
\text { adding institutional representation and } \\
\text { Governor-appointed members. }\end{array}$ & $\begin{array}{l}\text { Marcus, 1997; } \\
\text { McLendon and } \\
\text { Ness, } 2001\end{array}$ \\
\hline 1997 & Arkansas & $\begin{array}{l}\text { Replaced State Board of Higher Education } \\
\text { with Higher Education Coordinating } \\
\text { Board and reduced the number of staff } \\
\text { assigned to the board's administrative } \\
\text { arm, the Department of Higher Education; } \\
\text { reorganized Board's trustee selection } \\
\text { process to ensure greater campus } \\
\text { representation; created Executive Council } \\
\text { of presidents to work with the director of } \\
\text { the Department; gave the Executive } \\
\text { Council authority to hire and fire the } \\
\text { director and powers of appeal regarding } \\
\text { the Board's policy agenda. }\end{array}$ & $\begin{array}{l}\text { McLendon, 2000a; } \\
\text { McLendon and } \\
\text { Ness, } 2001\end{array}$ \\
\hline 1997 & Kentucky & $\begin{array}{l}\text { Created a coordinating body, the } \\
\text { Kentucky Council on Postsecondary } \\
\text { Education, which was charged with } \\
\text { implementing quality improvement and } \\
\text { accountability goals; created the Kentucky } \\
\text { Community and Technical College } \\
\text { System and transferred management of } \\
\text { the two-year colleges from the state } \\
\text { universities to the new system. }\end{array}$ & $\begin{array}{l}\text { Davis, 2001; } \\
\text { McLendon and } \\
\text { Ness, } 2001\end{array}$ \\
\hline
\end{tabular}




\section{Macrothink}

Global Journal of Educational Studies

ISSN 2377-3936

2015, Vol. 1, No. 1

\begin{tabular}{|c|c|c|c|}
\hline $\begin{array}{l}\text { Year of } \\
\text { Enactment }\end{array}$ & State & Nature of Reform & Data Source \\
\hline 1997 & Louisiana & $\begin{array}{l}\text { Clarified and strengthened the } \\
\text { constitutional authority of the Board of } \\
\text { Regents as state's coordinating body for } \\
\text { all public postsecondary education. }\end{array}$ & $\begin{array}{l}\text { McLendon and } \\
\text { Ness, } 2001\end{array}$ \\
\hline 1998 & Hawaii & $\begin{array}{l}\text { Recognized the University of Hawaii as a } \\
\text { "quasi-public corporation"; gave the } \\
\text { university greater management flexibility } \\
\text { in various areas including budget and } \\
\text { lands, faculty contracts, purchasing, and } \\
\text { legal representation. }\end{array}$ & $\begin{array}{l}\text { McLendon, 2000a; } \\
\text { McLendon and } \\
\text { Ness, 2001 }\end{array}$ \\
\hline 1998 & Louisiana & $\begin{array}{l}\text { Created the Louisiana Community and } \\
\text { Technical College System (LCTCS) and } \\
\text { transferred management authority for } \\
\text { state's } 44 \text { vocational-technical campuses } \\
\text { for state K- } 12 \text { board to the new LCTCS. }\end{array}$ & $\begin{array}{l}\text { McLendon and } \\
\text { Ness, } 2001\end{array}$ \\
\hline 1998 & Maryland & $\begin{array}{l}\text { Required Maryland Higher Education } \\
\text { Commission to develop a state plan for } \\
\text { higher education and changed its role in } \\
\text { review and approval of mission } \\
\text { statements, budget, and funding } \\
\text { guidelines; established University System } \\
\text { of Maryland as an independent unit of } \\
\text { state government, exempt from laws } \\
\text { governing procurement, information } \\
\text { technology, and telecommunications; } \\
\text { allowed the Board of Regents of USM to } \\
\text { delegate to each institution's president } \\
\text { authority to implement policies promoting } \\
\text { the institution's mission. }\end{array}$ & $\begin{array}{l}\text { McLendon and } \\
\text { Ness, } 2001\end{array}$ \\
\hline 1999 & Kansas & $\begin{array}{l}\text { Reconstituted the Kansas Board of } \\
\text { Regents; transferred supervision of } \\
\text { community colleges and vocational } \\
\text { schools from the Board of Education to } \\
\text { the Board of Regents. }\end{array}$ & $\begin{array}{l}\text { McLendon and } \\
\text { Ness, } 2001\end{array}$ \\
\hline 2000 & Hawaii & $\begin{array}{l}\text { Placed on the statewide election ballot an } \\
\text { amendment to the constitution providing } \\
\text { that all matters regarding internal structure } \\
\text { and management of the University of } \\
\text { Hawaii are the sole responsibility of the } \\
\text { UH Board of Regents; eliminated the } \\
\text { requirement that UH must receive } \\
\text { legislative authorization before } \\
\text { formulating policy. (Voters approved } \\
\text { amendment in November, 2000.) }\end{array}$ & $\begin{array}{l}\text { McLendon and } \\
\text { Ness, } 2001\end{array}$ \\
\hline 2001 & Florida & $\begin{array}{l}\text { Abolished the Board of Regents of the } \\
\text { State University System, a consolidated } \\
\text { governing board with central management } \\
\text { authority of state's } 10 \text { universities; }\end{array}$ & $\begin{array}{l}\text { McLendon and } \\
\text { Ness, } 2001\end{array}$ \\
\hline
\end{tabular}




\section{Appendix 2. Framework for determining the level of accreditation in Australia}

\begin{tabular}{ll} 
Table 1: Australian Qualifications Framework \\
\hline Level & Quallflcation \\
\hline 1 & Certificate I \\
2 & Certificate II \\
3 & Certificate III \\
4 & Certificate IV \\
5 & Diploma \\
6 & Advanced Diploma; Associate Degree \\
7 & Bachelor Degree \\
8 & Bachelor Honours Degree; Graduate \\
9 & Certificate; Graduate Diploma \\
10 & Masters Degree \\
\hline
\end{tabular}

Source: AQF (2013)

\section{Appendix 3. Different types of government funding}

\begin{tabular}{|c|c|c|c|}
\hline Category & Sub-category & Description & Millions \\
\hline $\begin{array}{l}\text { Teaching } \\
\text { grants } \\
(\sim \$ 6.2 \text { bn) }\end{array}$ & $\begin{array}{l}\text { Commonwealth } \\
\text { Grant Scheme }\end{array}$ & $\begin{array}{l}\text { Funding based on the number of } \\
\text { supported domestic student } \\
\text { places. See section } 5.2 .1 \text { for more } \\
\text { detail }\end{array}$ & $\$ 6,222$ \\
\hline $\begin{array}{l}\text { Loan costs } \\
\text { ( } \$ 1.5 \text { bn) } \\
\text { (Distinct } \\
\text { from new } \\
\text { loans of } \sim \\
\$ 5.5 \text { bn) }\end{array}$ & $\begin{array}{l}\text { Higher } \\
\text { Education Loan } \\
\text { Program: } \\
\text { HECS-HELP, } \\
\text { FEE-HELP, } \\
\text { OS-HELP, } \\
\text { SA-HELP }\end{array}$ & $\begin{array}{l}\text { Costs include interest subsidies, } \\
\text { debt not expected to be repaid, } \\
\text { and discounts for up-front payment } \\
\text { or early repayment. Section } 5.2 .2 \\
\text { for more detail. }\end{array}$ & $\$ 1,488$ \\
\hline \multirow{4}{*}{$\begin{array}{l}\text { Income } \\
\text { support for } \\
\text { students } \\
(\sim \$ 2.9 \text { bn) }\end{array}$} & $\begin{array}{l}\text { Aus. Postgrad. } \\
\text { Awards }\end{array}$ & $\begin{array}{l}\text { Living expense support for } \\
\text { postgraduate students. } \\
\text { Section } 5.2 .3\end{array}$ & $\$ 266$ \\
\hline & $\begin{array}{l}\text { Youth } \\
\text { Allowance }\end{array}$ & $\begin{array}{l}\text { Living expense support for } \\
\text { students aged } 16-24 \text {. } \\
\text { Section } 5.2 .3\end{array}$ & $\$ 2,151$ \\
\hline & Austudy & $\begin{array}{l}\text { Living expense support for } \\
\text { students aged } 25 \text { or more. } \\
\text { Section } 5.2 .3\end{array}$ & $\$ 479$ \\
\hline & Abstudy & $\begin{array}{l}\text { Support for living expenses for } \\
\text { Indigenous students. Section } 5.2 .3\end{array}$ & $\$ 47$ \\
\hline \multirow{4}{*}{$\begin{array}{l}\text { Research } \\
\text { grants } \\
(\sim \$ 3.0 \text { bn), } \\
\text { (Not } \\
\text { including } \\
\text { 'other } \\
\text { recurrent } \\
\text { grants') }\end{array}$} & \multirow{2}{*}{$\begin{array}{l}\text { Competitive } \\
\text { research grants }\end{array}$} & ARC - section 5.2.4 & $\$ 890$ \\
\hline & & NHMRC - section 5.2 .4 & $\$ 614$ \\
\hline & $\begin{array}{l}\text { Performance- } \\
\text { based block } \\
\text { research grants }\end{array}$ & $\begin{array}{l}\text { Research training and general } \\
\text { research funding. Funding is } \\
\text { based on research activity. } \\
\text { Section } 5.2 .4\end{array}$ & $\$ 1,459$ \\
\hline & $\begin{array}{l}\text { Other recurrent } \\
\text { grants }\end{array}$ & $\begin{array}{l}\text { For example: equity, national } \\
\text { institutes, TEQSA. }\end{array}$ & $\$ 463$ \\
\hline Total & & & $\$ 14,079$ \\
\hline
\end{tabular}




\section{Mll Macrothink \\ Global Journal of Educational Studies \\ ISSN 2377-3936 \\ 2015, Vol. 1, No. 1}

\section{Appendix 4. Eligibility for funding by category}

\begin{tabular}{|c|c|c|c|c|c|}
\hline Fundlng Type & Table A & Table B & Table C & $\begin{array}{l}\text { Other HE } \\
\text { providers }\end{array}$ & OUAA $^{\wedge}$ \\
\hline $\begin{array}{l}\text { FEE-HELP } \\
\text { loans }\end{array}$ & $\checkmark$ & $\checkmark$ & $\checkmark$ & $\checkmark$ & $\checkmark$ \\
\hline $\begin{array}{l}\text { Commonwealth } \\
\text { supported } \\
\text { places and } \\
\text { HECS-HELP } \\
\text { loans }\end{array}$ & $\checkmark$ & $\begin{array}{c}\checkmark \\
\text { (provided the } \\
\text { place is in a } \\
\text { 'national } \\
\text { priority' } \\
\text { category')* }\end{array}$ & $\begin{array}{l}\checkmark \\
\text { (provided the } \\
\text { place is in a } \\
\text { 'national priority' } \\
\text { category') }{ }^{*} \text { [none } \\
\text { in 2014] }\end{array}$ & $\begin{array}{c}\checkmark \\
\text { (provided the } \\
\text { place is in a } \\
\text { 'national } \\
\text { priority' } \\
\text { category')" }\end{array}$ & $\begin{array}{l}\sim \\
\text { Indirectly } \\
\text { via } \\
\text { universities } \\
\text { delivering } \\
\text { award } \\
\text { programs }\end{array}$ \\
\hline
\end{tabular}

\begin{tabular}{|c|c|c|c|c|c|}
\hline $\begin{array}{l}\text { Research block } \\
\text { grants }\end{array}$ & $\checkmark$ & $\checkmark$ & $x$ & $x$ & $x$ \\
\hline $\begin{array}{l}\text { Research } \\
\text { training places }\end{array}$ & $\checkmark$ & $\checkmark$ & $x$ & $x$ & $x$ \\
\hline $\begin{array}{l}\text { ARC } \\
\text { competitive } \\
\text { grants }\end{array}$ & $\checkmark$ & $\checkmark$ & $x$ & $x$ & $x$ \\
\hline NHMRC grants & $\checkmark$ & $\checkmark$ & $\checkmark$ & $x$ & $x$ \\
\hline $\begin{array}{l}\text { Student income } \\
\text { support }\end{array}$ & $\checkmark$ & $\checkmark$ & $\checkmark$ & $\checkmark$ & $\checkmark$ \\
\hline
\end{tabular}

Notes:^Open Universities Australia; ${ }^{*}$ Based on ministerial decision. Though NHMRC guidelines would permit Table $C$ institutions to receive grants, none do.

\section{Copyright Disclaimer}

Copyright for this article is retained by the author(s), with first publication rights granted to the journal.

This is an open-access article distributed under the terms and conditions of the Creative Commons Attribution license (http://creativecommons.org/licenses/by/3.0/). 